\title{
Myopericytoma of the Liver Hilus: A Case Report
}

\author{
Karaciğer Hilusunda Myoperisitom: Olgu Sunumu
}

\author{
Amedeo FERLOSIO', Tommaso Maria MANZIA², Lucia ANEMONA', Giuseppe TISONE², Augusto ORLANDI ${ }^{1}$ \\ ${ }^{1}$ Department of Biomedicine and Prevention, Anatomic Pathology Institute, Tor Vergata University of Rome, ROME, ITALY \\ ${ }^{2}$ Department of Experimental Medicine and Surgery, Transplantation Surgery, ROME, ITALY
}

\begin{abstract}
Pericytic tumours is a new category recently introduced in soft tissue pathology describing those entities sharing evidence of myoid differentiation and a tendency of spindle or more rounded cells to grow in a perivascular fashion. The great majority of pericytic tumours are benign but recurrence has been described as well as very rare malignant cases with an aggressive behaviour. Although pericytic tumours arise most commonly in the subcutaneous tissue of distal extremities in middle age patients, additional cases have been recently described in many other organs. Here we describe a case of a 57-year-old man with an $8.5 \mathrm{~cm}$ mass of the liver hilus diagnosed as myopericytoma, with particular reference to its biological potential and differential diagnosis. It is important for the pathologists to take this diagnosis into consideration as well for a better management of patient care.
\end{abstract}

Key Words: : Smooth muscle, Liver, Differential diagnosis

\section{ÖZ}

Yumuşak doku patolojisinde son zamanlarda tanımlanan yeni bir kategori olan perisitik tümör, myoid diferansiasyon gösteren iğsi ya da yuvarlak hücrelerin perivasküler büyüme patterni oluşturduğu tümörlerin tanımlandığı bir antitedir. Perisitik tümörlerin büyük bir bölümü benigndir, ancak nüks ve agresif davranış gösteren malign olgular da nadiren bildirilmiştir. Genelde, orta yaşlı hastalarda distal ekstremitelerin subkütan dokularından kaynaklansalar da, son yıllarda diğer organlardan kaynaklanan olgular da bildirilmiştir. $\mathrm{Bu}$ olgu sunumunda, karaciğer hilusu kaynaklı $8,5 \mathrm{~cm}$ çapında kitlesi olan ve myoperisitom tanısı alan 57 yaşında erkek hasta tanımlanmakta ve özellikle tümörün biyolojik potansiyeli ve ayırıcı tanısı üzerinde durulmaktadır. Patologların bu tümörü de ayırıcı tanı içerisine almaları, hastaya daha iyi bir yaklaşım açısından önemlidir.

Anahtar Sözcükler: Düz kas, Karaciğer, Ayırıcı tanı

\section{INTRODUCTION}

In the most recent WHO classification of soft tissue tumours, the category named "pericytic (perivascular) tumours" has been included (1). Previously, Requena et al. introduced the term "myopericytoma" as an alternative designation for solitary myofibroma, based on the supposed myopericytic differentiation of the tumour (2). The term "myopericytoma" encompasses a morphological spectrum of tumours including glomus tumours, myofibromatosis and infantile haemangiopericytoma, characterized by spindle cells with contractile features and various arrangement around blood vessels (3-6). For this reason, the 2013 WHO classification of soft tissue tumours introduced a category named pericytic (perivascular) rather than vascular tumours (1). The preferential site of involvement is subcutaneous tissue of distal extremities. However, the increased recognition of this entity showed wider sites of distribution, including the proximal extremities, the neck and more rarely visceral compartment.

\section{CASE REPORT}

A 57-year-old male was admitted to hospital for epigastric and right hypochondrium pain irradiated to the chest. Past medical history was unremarkable. An abdominal ultrasonography revealed gallstones and a non-homogeneous solid lesion of $8.5 \mathrm{~cm}$ in diameter located between the vena cava, aorta and hepatic hilum. The laboratory tests showed neither liver dysfunction nor markers level flare. Abdominal computerized tomography revealed a hypodense parenchymal formation with a homogeneous contrast enhancement (Figure 1). The lesion was $9.1 \times 7.8 \times 6.6 \mathrm{~cm}$ and involved the hepatic hilum, the segment IV of the liver and the wall of the vena cava. Endoscopic ultrasound-guided fine needle aspiration biopsy did not provide sufficient material for a diagnosis. An exploratory laparotomy was performed. Intraoperative ultrasonography showed no involvement of adjacent structures and the tumour was resected. 


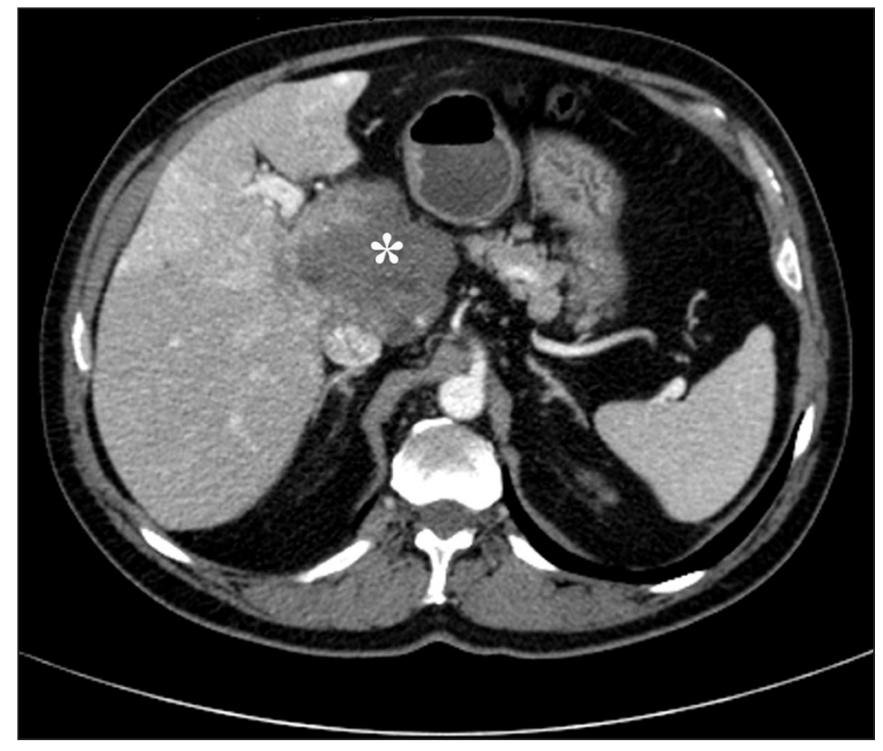

Figure 1: Abdominal Computerized Tomography: Scan image showing hypodense formation $\left(^{*}\right)$ with a homogeneous contrast enhancement involving the hepatic hilum, the segment IV of the liver and the wall of the vena cava.

Macroscopically, the tumour was apparently well capsulated, multi-lobated with a greyish cut surface and hemorrhagic alternated to sclerotic areas. Microscopically, a thin fibrous capsule incompletely delimitated the tumour mass which was focally infiltrated the liver parenchyma (Figure 2A). The tumour was mainly characterized by "staghorn-like" vascular branching spaces surrounded by spindle or epithelioid cells sometimes with abundant clear cytoplasm embedded in a rich myxoid stroma (Figure 2BD). Alternating, sclerotic areas and "solid growth" were characterized by small vessels with fascicular arrangements of neoplastic cells (Figure 2E-F). A multilayered concentric proliferation of spindle cells with myoid features around blood vessels was also observed (Figure 2G-H). Atypia and mitosis were absent. Small areas of coagulative necrosis were detected probably due to the previously performed fine needle aspiration biopsy.

Immunohistochemical examination revealed that tumour cells were $\alpha$-smooth muscle actin positive (Figure $3 \mathrm{~A}$ ) whereas CD34 (Figure 3B), CD31 (except for endothelial cells covering the vascular spaces), CD99 and bcl-2 immonodetection were negative. The proliferative index evaluated by $\mathrm{Ki}-67$ nuclear positivity was lower than $1 \%$ (Figure 3C). Concentric proliferations of spindle cells around vessels were $\alpha$-smooth muscle actin positive (Figure 3D). A diagnosis of myopericytoma was made. After 24 months, the patient is alive with no recurrence.

\section{DISCUSSION}

"Pericytic tumours" are a new entity describing tumours with perivascular myoid, myopericytic or myofibroblastic differentiation enclosing the diagnosis of myopericytoma and glomus tumour with its variants (1-3). The differences between these tumours are largely based on cell morphology (more rounded or spindle cells), growth pattern and the presence of a prominent vascular component so representing a morphological continuum. They arise most commonly in subcutaneous tissue of distal extremities in middle aged patients; however, lesions can arise at any age and anywhere $(1,4,6,7)$. According to the literature, just few cases of primary glomus tumour of the liver have been described. Moreover, only one case of myopericytoma of the liver are reported in a patient with HIV infection and with multiple (intracranial, hepatic and spinal epidural) tumours demonstrated histologically by biopsies (8). This might depend more on its intrinsic rarity, because until now this tumour has been enrolled among the diagnosed cases of hemangioma or hemangiopericytoma. The differential diagnosis of the pericytic tumours includes both benign and malignant vascular neoplasms, the so-called hemangiopericytoma and other fibroblastic/ myofibroblastic tumours, and finally true smooth muscle tumours. Nowadays, the term hemangiopericytoma is no more accepted and has been replaced with the term "extrapleural fibrous tumour" for its fibroblastic origin (3). The great majority of hemangiopericytoma expresses CD34 and CD99 antigens by immunohistochemistry, while only a minority are bcl-2 and $\alpha$-smooth muscle actin positive (1). Hemangiomas are tumours characterized by proliferation of vessels with scarcely intermingled mesenchymal component and malignant vascular tumours show marked endothelial atypia (1). PEComas are tumours that display both spindle and epithelioid cells with clear cytoplasm resembling renal clear cell tumour and exhibiting atypia, mitosis and necrosis with an infiltrative pattern (1). Moreover, PEComa cells have a prevalent perivascular pseudorosetting disposition around delicate vessels with arborizing capillaries co-expressing neuromelanocytic (such as HMB-45) and myocytic markers (3).

Although generally benign, pericytic tumours can recur following excision. Recurrence is usually related to poor circumscription of a lesion and so incomplete surgical removal. Moreover, true malignant cases of perivascular tumour with distant metastasis have been rarely described (9). 


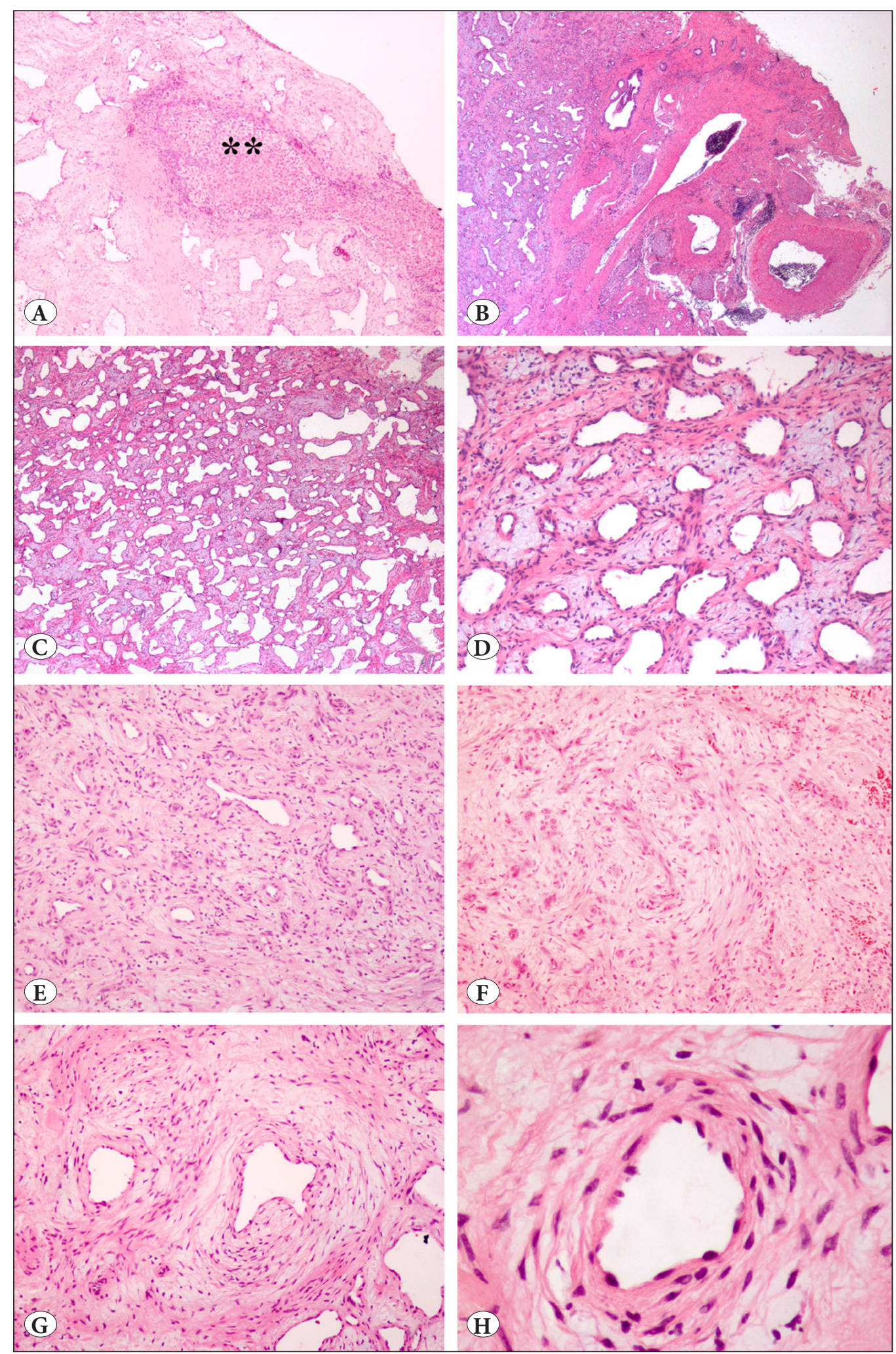

Figure 2: Microscopic findings: representative pictures showing A) The tumour focally infiltrating the liver parenchyma (**) (H\&E; $\mathrm{x} 20$ ) and B) Arising in close conjunction with major hilar vessels (H\&E; x20), C,D) The characteristic "staghorn-like" branching vascular spaces surrounded by spindle or epithelioid cells embedded in a myxoid stroma (H\&E; x20 and H\&E; x100), E,F) more solid areas with fascicular elongated cells around small vessels (H\&E; x100), and $\mathbf{G}, \mathbf{H}$ ) Characteristic concentric proliferation of spindle cells around vessels (H\&E; x100 and H\&E; x400). 

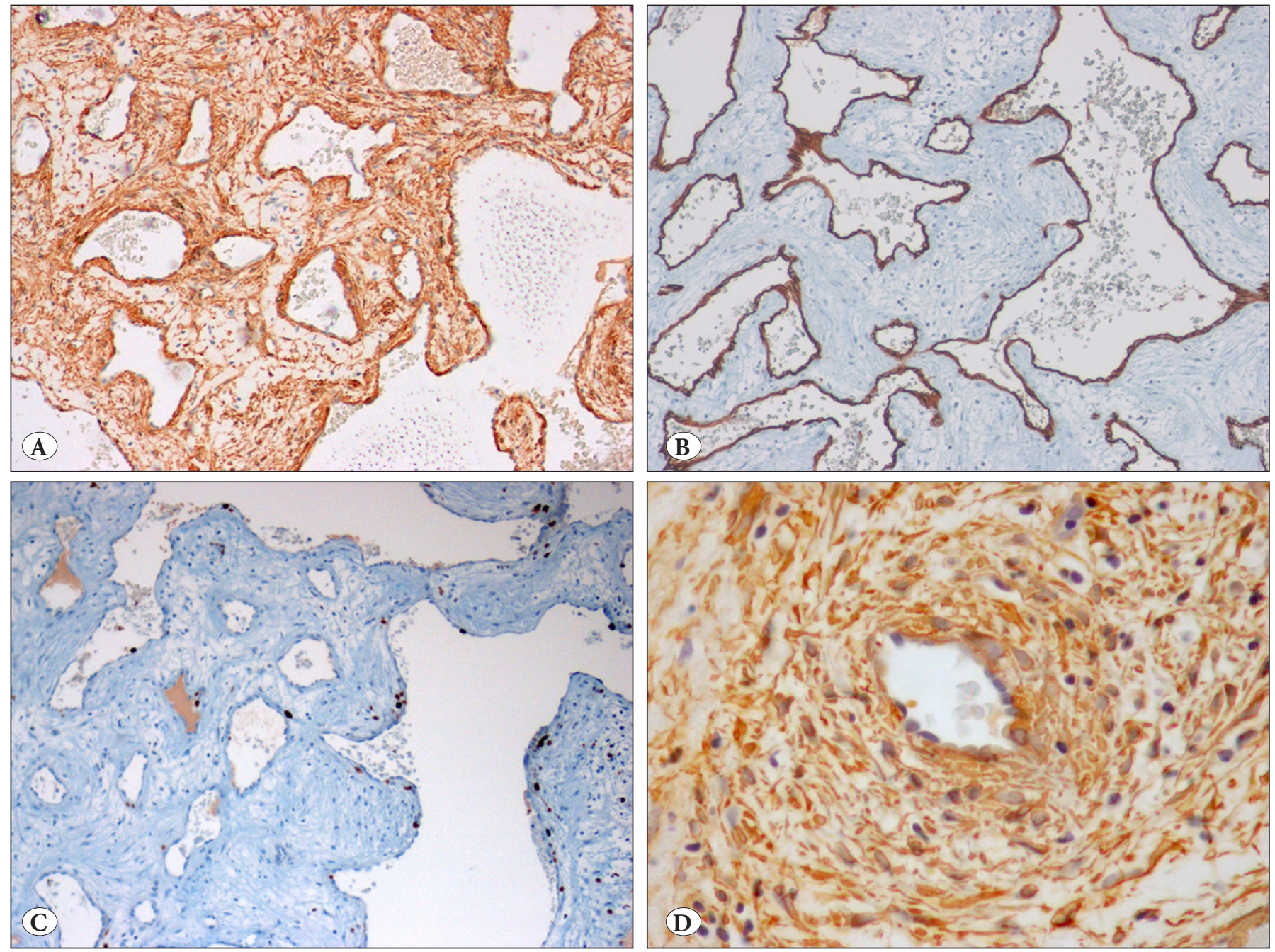

Figure 3: Immunohistochemical findings: tumour cells were A) a-smooth muscle actin positive (SMA; x20) and B) CD34 negative; instead, endothelial cells covering the vascular spaces are CD34 positive, (CD34; x20) C) proliferative index evaluated by ki-67 expression was very low (Ki-67; x20), D) detail of characteristic concentric proliferation of spindle cells around vessels highlighted by a-smooth muscle actin positivity (SMA; $\mathrm{x} 400)$.

Nevertheless, the histological aspect is not always predictive of the clinical behaviour of some tumours, especially those exhibiting "glomus-type" features (9). High mitotic activity (typical and atypical), the large tumour size and visceral location are diagnostic criteria of malignancy $(1,9)$. When a tumour does not fulfill all these criteria, the designation "uncertain malignant potential" seems to be appropriate, suggesting a possible more aggressive biological behavior. The presence of a prominent vascularization suggests a potential target for additional post-surgical therapy of more aggressive cases $(10,11)$.

In conclusion, it is important to take the possibility of a pericytic tumour into consideration for a correct differential diagnosis of primary liver neoplasms for a better management of patient care.

\section{REFERENCES}

1. Fletcher CDM, Bridge JA, Hogendoorn P, Mertens F. WHO Classification of Tumours of Soft Tissue and Bone. 4th ed. Lyon: IARC Press; 2013.

2. Requena L, Kutzner H, Hügel H, Rütten A, Furio V. Cutaneous adult myofibroma: A vascular neoplasm. J Cutan Pathol. 1996;23:445-57.

3. Fletcher CD. The evolving classification of soft tissue tumours: An update based on the new WHO classification. Histopathology. 2006;48:3-12.

4. Granter SR, Badizadegan K, Fletcher CD. Myofibromatosis in adults, glomangiopericytoma, and myopericytoma: A spectrum of tumors showing perivascular myoid differentiation. Am J Surg Pathol. 1998;22:513-25. 
5. Kutzner H. Perivascular myoma: A new concept for "myofibroblastic" tumors with perivascular myoid differentiation. Verh Dtsch Ges Pathol. 1998;82:301-8.

6. Li XQ, Hisaoka M, Morio T, Hashimoto H. Intranasal pericytic tumors (glomus tumor and sinonasal hemangiopericytoma-like tumor): Report of two cases with review of the literature. Pathol Int. 2003;53:303-8.

7. Orlandi A, Ferlosio A, Ciucci A, Pellegrino A, Spagnoli LG. Unusual cardiac tumour with perivascular myoid differentiation: A case report. J Clin Pathol. 2004;57:1338-40.

8. Calderaro J, Polivka M, Gallien S, Bertheau P, Thiebault JB, Molina JM, Gray F. Multifocal Epstein Barr virus (EBV)associated myopericytoma in a patient with AIDS. Neuropathol Appl Neurobiol. 2008;34:115-7.
9. McMenamin ME, Fletcher CD. Malignant myopericytoma: Expanding the spectrum of tumours with myopericytic differentiation. Histopathology. 2002;41:450-60.

10. Tarallo V, Vesci L, Capasso O, Esposito MT, Riccioni T, Pastore L, Orlandi A, Pisano C, De Falco S. A placental growth factor variant unable to recognize vascular endothelial growth factor (VEGF) receptor-1 inhibits VEGF-dependent tumor angiogenesis via heterodimerization. Cancer Res. 2010;70:1804-13.

11. Cassinelli G, Zuco V, Petrangolini G, De Cesare M, Tortoreto M, Lanzi C, Cominetti D, Zaffaroni N, Orlandi A, Passeri D, Meco D, Di Francesco AM, Riccardi R, Bucci F, Pisano C, Zunino F. The curative efficacy of namitecan (ST1968) in preclinical models of pediatric sarcoma is associated with antiangiogenic effects. Biochem Pharmacol. 2012; 84:163-71. 